Effect of Melia azedarach on The Reproductive Efficiency in Female Rabbits

Mayada Nazar Al-Khafaji

\title{
Effect of Melia azedarach on The Reproductive Efficiency in Female Rabbits
}

\author{
Mayada Nazar Al-Khafaji \\ Department of Biology- College of Sciences- University of Diyala- Diyala, Iraq
}

Received: 2 October 2015

Accepted: 16 May 2016

\begin{abstract}
$\underline{\text { Abstract }}$
Various types of contraceptives were developed. These contraceptives are prepared from natural as well as synthetic sources. The study was conducted on 15 mature adult females, and males of rabbits.10 from each female and male rabbits were treated with Melia azedarach in powder form at a dose rate of $6 \mathrm{~g} / \mathrm{kg}$ b.wt. Orally mixed with feed daily for 53days, the remaining 5 from each of female and male rabbits remain non treated. In $28^{\text {th }}$ day post exposure to Melia; the animals were divided into 3 groups. Group I represented females non treated with plant crossed with treated males. Group II represented treated females crossed with non treated males. Group III represented non treated females crossed with non treated males. The mixing continued for 10 days. All females were examined for pregnancy by sonar weekly. At $56^{\text {th }}$ day post treatment with plant 3 females from each group were killed, while others 2 female rabbits were left till birth. Size, weight and characters of naturally birthed fetuses and those found during explore the uterine horns of killed rabbits were fixed. Other dependent parameters in this study were hematological and some of constituents of serum. The results of the study revealed a non significant decrease in body weight, body temperature, heart rates, respiratory rate, clotting time and bleeding time. Erythrocytes counts, PCV, MCV values were not significantly increased in treated group, while in non treated group these were not significantly decreased. $\mathrm{Hb}, \mathrm{MCH}, \mathrm{MCHC}$ were not significantly changed in both groups. Total leucocytes count in treated group were decreased, whilst increased in non treated group. Heterophils\% were decreased in treated group. Lymphocytes percentage in treated group were increased, on other hand monocytes, eosinophil and basophils percentages did not show any significant
\end{abstract}


Effect of Melia azedarach on The Reproductive Efficiency in Female Rabbits

Mayada Nazar Al-Khafaji

changes. The results revealed that infertility index was 0,20 and $100 \%$ in group I, II and III respectively. Significant decrease in numbers, body weight, body length and width of skull of fetuses from females treated with extract of Melia, and those crossed with treated male in comparison with those of non treated females and males. The results revealed that treatment with Melia extract for 53 days did not affect the length of pregnancy in female treated with Melia extract. The results revealed that levels of ALT, AST and AP were higher in treated females in comparison with those of non treated rabbits. Values of FSH, LH, Prolactin and testosterone were less than normal levels,

Key words: Reproductive efficiency, Female rabbits, Melia azedarach

\section{تأثثير نبات السبحبح Melia azedarach في الكفاءة التناسلية لإناث الأرانب ميادة نزار الخفاجي}

قسم علوم الحياة ـ كلية العلوم - جامعة ديالى - ديالى ـ العراق

\section{الخلاصة}

نم تطوير أنو اع مختلفة من مو انع الحمل ، و التي تختلف في طريقة تأثير ها. تحضــر هذه الموانع من مصـــادر طبيعية

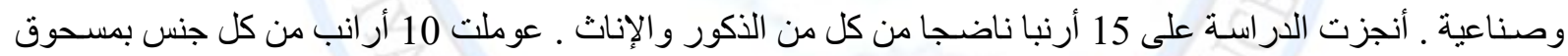
نبات السبحبح ( Melia azedarach ) ممزوج مع العلف ، وبجر عة يومية بمعدل 6 ملغم اكغم من وزن الجسم ، ولمدة

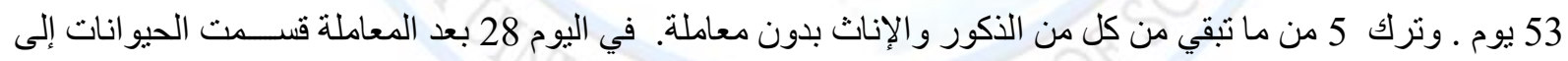
ثلاثة مجاميع ـ المجموعة الأولى مثلت الإنات غير المعاملة والتي زوجت مع ذئ ذكور معاملة بمسـحوف النبات، أما المجموعة الثانية فمثلت الإناث المعاملة بمسحوق النبات و التي زوجت مع ذكور غير معاملة ، في حين في المجمو عة الثالثة نم تزاوج

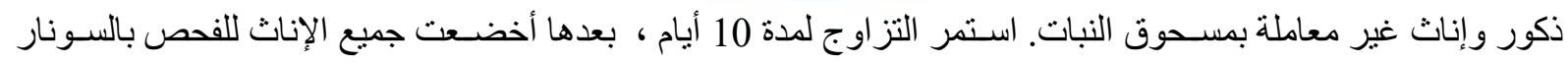
أسـبو عيا بحثا عن حصــول الحمل ـ في اليوم 56 من بدء التعامل بمسـحوق النبات تم ذبح 3 إناث من كل مجمو عة بحثنا عن حصـول الحمل من عدمه ، و عد الأجنة ووزنها وتثبيت خصـائصـها من طول الجسم و عرض الجمجمة في حالة حصـول الحمل ـ أما ما تبقى من الإناث 2 من كل مجمو عة فترك لحين إكمال الحمل و الولادة الطبيعية ـ من المعايير الأخرى التي متي

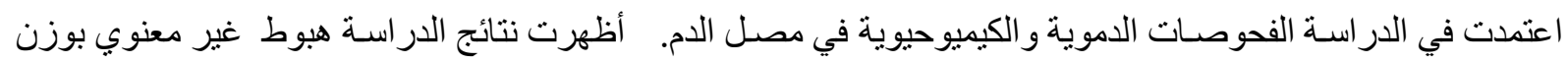
الجسم ، ودرجة حر ارة الجسم ، وضربات القلب ، و سرعة التنفس ، وزمن التخثر ، وزمن النزف. في حين حصلت زيادة

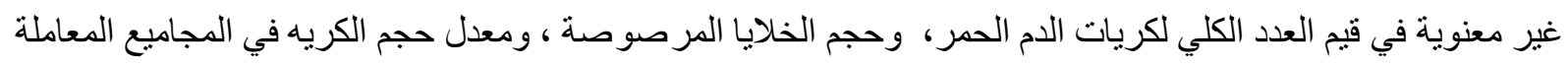
، لكنها هبطت هبوطا غير معنويا في المجاميع غير المعاملة. بينما لم يحصـل تغير معنوي في قيم خضـــاب الدم ، ومعدل 
Effect of Melia azedarach on The Reproductive Efficiency in Female Rabbits

Mayada Nazar Al-Khafaji

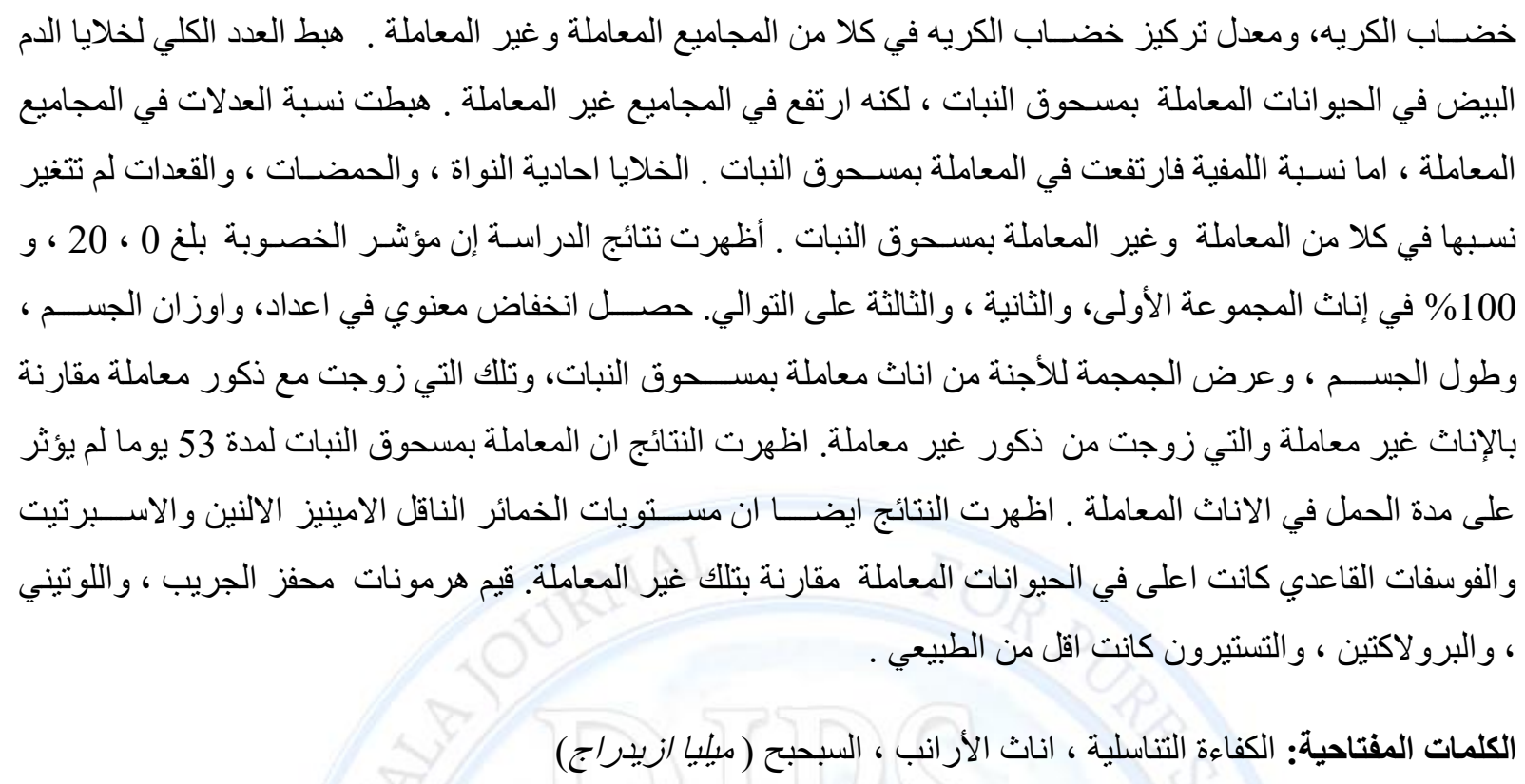

\section{$\underline{\text { Introduction }}$}

The contraceptives were worked by prevent the fusion of sperm into ovum, change female hormonal levels and spermicidal activity (1). Rapid rise in population has caused serious problem in economic growth and human development. Family planning has been promoted through several methods of contraception, but due to serious adverse effects, such as hormonal imbalance, hypertension, and increased risk of cancer and weight gain, the search for new antifertility molecule with minimum side effects continues. Hydro alcoholic extract of Melia azedarach linn roots were evaluated for anti-implantation, estrogenic, ant estrogenic and progestational, anti-progestational activity. It was found that the extract has very significant ant implantation and anti-progestational activity and devoid of estrogenic, anti- estrogenic activity. (2). Melia azedarch L. belong to family Meliaceae, subfamily Meloideae (3). Herbs are used for thousands of centuries by many cultures for their medicinal values. Herbal treatment is very popular because it is easily available, cheap and less toxic (4).

Several workers reported the anti-fertility activity of different parts of this plant. Many researchers reported that there was significant decrease in the number of normal follicle in ovaries of rat, if polar and nonpolar fractions, of Melia azedarach linn seed extract was 
Effect of Melia azedarach on The Reproductive Efficiency in Female Rabbits

Mayada Nazar Al-Khafaji

administered at $24 \mathrm{mg} / \mathrm{kg}$ for 18 days (5). Ethanolic extract of Melia azedarach intercepted pregnancy in $60 \%$ and $75 \%$ adult female rats (6). The seed oil of Azadirachta indica A. Juss (neem) is used in traditional medicine for its anti- diabetic, spermicidal, anti-fertility, antibacterial, and wound healing properties (5). The effect of oral administration of Melia azedarach Linn ( dharek) seed extract on fertility index, uterine weight and various histological and biochemical parameters of uterus were studied in the adult cyclic Wistar rats. Average number of embryos and implantation losses in the pregnant animals treated with dharek seed extract was also studied (2). Antifertility activity of Azadirachta indica (neem) and Melia azedarach (dharek) on the ovaries has been reported earlier $(5,7)$.

\section{$\underline{\text { Material and Methods }}$}

The study was conducted on 15 mature female, and 15 mature male rabbits of $1-2 \mathrm{~kg} \mathrm{b.wt,} 1-2$ years old. after acclimatization for 2 weeks under room temperature of $25 \pm 1^{\circ} \mathrm{C}$, and $12 \mathrm{~h} \mathrm{light,}$ $12 \mathrm{~h}$ dark conditions. 10 from each of males and females were treated with Melia azedarach in powder form at a dose rate of $6 \mathrm{~g} / \mathrm{kg}$ b.wt. orally mixed with feed daily for 53days, 5 from remaining females and males remain without treatment as non treated. In $27^{\text {th }}$ day post treatment with Melia; the animals were divided into 3 groups: male with female 1:1. Group I represented treated females crossed with non treated males. Group II represented non treated females crossed with treated males. Group III represented non treated females crossed with non treated males. The crossing continued for 10 days. Females of all three groups were examined for pregnancy by sonar weekly. At $56^{\text {th }}$ day post exposure to plant $\left(28^{\text {th }}\right.$ day post crossing with male). 3 females from each group were killed, while others 2 females from each group were left to complete pregnancy time till normal birth.

\section{Examine the Pregnancy Period and Number of Fetuses}

Genital system of killed rabbits from each of the three groups were examined, as the abdomen was opened, explore the uterine horns, which opened to measure the fetuses and their numbers if there were pregnancy, in addition to calculate resorption number if present.

Others dependent parameters in the study include hematological examination according to (8), in addition to some constituents in serum (kits methods) 
Effect of Melia azedarach on The Reproductive Efficiency in Female Rabbits

Mayada Nazar Al-Khafaji

\section{Statistical Analysis}

The data were analyzed by one way analysis of variance. The means were separated following Duncan test (9), at the level of $\mathrm{P}<0.05$

\section{$\underline{\text { Results }}$}

Results of this study revealed not significant decrease in body weight of treated group at $44^{\text {th }}$ day in comparison with previous days, but in both treated and non treated groups there were not significantly increase in comparison with previous days. Body temperature in treated and non treated groups was decreased in the $39^{\text {th }}$ day. Heart rates decreased in treated group in $56^{\text {th }}$ day in comparison with previous days and with values on non treated group. Rrespiratory rate in treated group was not decreased significantly in the $39^{\text {th }}, 44^{\text {th }}$ and $56^{\text {th }}$ day in comparison with previous days (Table-1-).

Table -1- Clinical Parameters of Rabbits in Experiment

\begin{tabular}{|c|c|c|c|c|c|}
\hline \multirow{2}{*}{ Parameter } & \multirow{2}{*}{ Group } & \multicolumn{4}{|c|}{ Day } \\
\cline { 3 - 6 } & & 0 & 39 & 44 & 56 \\
\hline Body Weight & I & $1.366 \pm 0.108$ & $1.316 \pm 0.109$ & $1.298 \pm 0.140$ & $1.445 \pm 0.005$ \\
\cline { 2 - 6 } Kg & II & $1.370 \pm 0.106$ & $1.355 \pm 0.085$ & $1.326 \pm 0.103$ & $1.450 \pm 0.115$ \\
\hline $\begin{array}{c}\text { Body Temperature } \\
{ }^{\circ} \mathrm{C}\end{array}$ & I & $38.73 \pm 0.36$ & $37.96 \pm 0.42$ & $38.7 \pm 0.40$ & $38.27 \pm 0.42$ \\
\cline { 2 - 6 } & II & $38.74 \pm 0.44$ & $37.99 \pm 0.23$ & $38.42 \pm 0.18$ & $38.02 \pm 0.29$ \\
\hline $\begin{array}{c}\text { Heart } \\
\text { Rate/min }\end{array}$ & I & $176 \pm 11.66$ & $177.5 \pm 6.88$ & $183 \pm 10.75$ & $161.33 \pm 1.33$ \\
\cline { 2 - 6 } & II & $180 \pm 9.17$ & $175.1 \pm 11.28$ & $188.8 \pm 7.84$ & $180.8 \pm 11.20$ \\
\hline $\begin{array}{c}\text { Respiratory. } \\
\text { Rate/min }\end{array}$ & I & $172 \pm 18.0$ & $130 \pm 5.77$ & $137 \pm 15.78$ & $136.34 \pm 16.71$ \\
\cline { 2 - 6 } & II & $173.6 \pm 13.30$ & $168.2 \pm 8.23$ & $168 \pm 10.66$ & $173.6 \pm 13.00$ \\
\hline
\end{tabular}

Values are $\mathrm{M} \pm$ SEM: I treated group; II. Non treated group.

Clotting time in treated group significantly decreased in the $23^{\text {rd }}, 44^{\text {th }}$ and $56^{\text {th }}$ in comparison with previous values and with values of non treated group. Bleeding time in treated group not significantly decreased in the $44^{\text {th }}$ day in comparison with previous days (Table-2- ). 
Effect of Melia azedarach on The Reproductive Efficiency in Female Rabbits

Mayada Nazar Al-Khafaji

Table -2- Clotting and Bleeding time of Rabbits in Experiment

\begin{tabular}{|c|c|c|c|c|c|}
\hline \multirow{2}{*}{ Parameter } & \multirow{2}{*}{ Group } & \multicolumn{4}{|c|}{ Day } \\
\cline { 3 - 6 } & & 0 & 23 & 44 & 56 \\
\hline Clotting & I & $45 \pm 1.89 \mathrm{a}$ & $20 \pm 1.94 \mathrm{~b}$ & $28.75 \pm 2.57 \mathrm{~b}$ & $15.67 \pm 1.41 \mathrm{~b}$ \\
\cline { 2 - 6 } Time/ sec. & II & $40 \pm 1.17 \mathrm{a}$ & $42 \pm 1.17 \mathrm{a}$ & $45 \pm 1.04 \mathrm{a}$ & $50 \pm 1.32 \mathrm{a}$ \\
\hline Bleeding & I & $37 \pm 0.39$ & $36.25 \pm 1.34$ & $31.67 \pm 1.51$ & $36.67 \pm 2.99$ \\
\cline { 2 - 6 } Time/ sec & II & $35 \pm 0.79$ & $32 \pm 1.79$ & $33 \pm 2.57$ & $35 \pm 1.31$ \\
\hline
\end{tabular}

Values are $\mathrm{M} \pm$ SEM: I treated group; II. Non treated group: a, $b$ significant difference at a level of $\mathrm{P}<0.05$ in comparison with previous day

Erythrocytes counts in treated group was significantly decreased in the $23^{\text {rd }}, 44^{\text {th }}, 56^{\text {th }}$ day in comparison with previous days, the lowest counts was in the $44^{\text {th }}$ day, however in non treated group no changes was observed. Hemoglobin concentration was not changed significantly. PCV in treated group significantly decreased in the $56^{\text {th day }}$, in comparison with previous day. $\mathrm{MCV}$ values in treated group was not significantly increased in the $23^{\text {rd }}$ and $56^{\text {th }}$ day, but not significantly decreased in the $44^{\text {th }}$ day in comparison with previous day. There was not significant decreased In non treated group in day the $56^{\text {th }}$ day. whilst not significant changes in $\mathrm{MCH}, \mathrm{MCHC}$ in both groups (Table-3).

Table -3- Total Erythrocytes Count, Hb Concentration, PCV\% and Erythrocyte Indices of Rabbits in Experiment.

\begin{tabular}{|l|l|l|l|l|l|}
\hline \multirow{2}{*}{ Parameter } & \multirow{2}{*}{ Group } & \multicolumn{5}{|c|}{ Day } \\
\cline { 2 - 6 } & & \multicolumn{1}{|c|}{0} & \multicolumn{1}{c|}{23} & \multicolumn{1}{c|}{44} & \multicolumn{1}{c|}{56} \\
\hline \multirow{2}{*}{$\begin{array}{l}\text { RBCX10\% } \\
\mathrm{mm}^{3}\end{array}$} & I & $5.11 \pm 0.31 \mathrm{a}$ & $4.3 \pm 0.26 \mathrm{~b}$ & $3.85 \pm 0.06 \mathrm{~b}$ & $4.2 \pm 0.29 \mathrm{~b}$ \\
\cline { 2 - 6 } $\mathrm{Hb}$ g/dl & II & $5.12 \pm 0.44 \mathrm{a}$ & $4.94 \pm 0.25 \mathrm{a}$ & $4.79 \pm 0.43 \mathrm{a}$ & $5.23 \pm 0.64 \mathrm{a}$ \\
& I & $10.38 \pm 0.44$ & $10.13 \pm 0.70$ & $9.3 \pm 0.51$ & $9.68 \pm 0.39$ \\
\cline { 2 - 6 } & II & $9.36 \pm 0.45$ & $10.32 \pm 0.32$ & $9.18 \pm 0.81$ & $9.77 \pm 0.71$ \\
\hline \multirow{2}{*}{ PCV\% } & I & $33.2 \pm 1.36$ & $32 \pm 2.27$ & $33.67 \pm 0.88 \mathrm{a}$ & $30.5 \pm 1.04 \mathrm{~b}$ \\
\cline { 2 - 6 } & II & $33.2 \pm 1.36$ & $32.6 \pm 1.29$ & $31.6 \pm 2.84$ & $31.5 \pm 2.02$ \\
\hline MCVft & I & $66.37 \pm 6.15 \mathrm{a}$ & $74.32 \pm 1.87 \mathrm{a}$ & $62.70 \pm 5.38 \mathrm{a}$ & $73.65 \pm 4.37$ \\
\cline { 2 - 6 } & II & $69.73 \pm 6.68 \mathrm{a}$ & $72.84 \pm 5.27 \mathrm{a}$ & $77.66 \pm 2.02 \mathrm{a}$ & $70.02 \pm 5.41$ \\
\hline \multirow{2}{*}{ MCHpg } & I & $20.76 \pm 1.95$ & $23.53 \pm 0.56$ & $19.43 \pm 1.74$ & $20.20 \pm 1.10$ \\
\cline { 2 - 6 } & II & $21.69 \pm 2.03$ & $23.02 \pm 1.44$ & $22.91 \pm 0.68$ & $21.47 \pm 1.56$ \\
\hline MCHCg/dl & I & $31.25 \pm 0.06 \mathrm{a}$ & $31.65 \pm 0.11 \mathrm{a}$ & $30.98 \pm 0.15 \mathrm{a}$ & $31.02 \pm 0.6 \mathrm{a}$ \\
\cline { 2 - 6 } & II & $30.97 \pm 0.11$ & $31.71 \pm 0.5$ & $31.11 \pm 0.14$ & $31.04 \pm 0.21$ \\
\hline
\end{tabular}




\section{Effect of Melia azedarach on The Reproductive Efficiency in Female Rabbits}

Mayada Nazar Al-Khafaji

Values are $\mathrm{M} \pm$ SEM: I treated group; II. Non treated group; a, b significant difference at a level of $P<0.05$ in comparison with previous day.

Total leucocytes count was decreased in treated group in the $23^{\text {rd }}, 44^{\text {th }}$ and $56^{\text {th }}$ day in comparison with previous day, whereas in non treated group increased in the $23^{\text {rd }}$ and $56^{\text {th }}$ day. Heterophils\% decreased in treated group at $23^{\text {rd }}$ day. Lymphocytes percentage in treated group was increased at $23^{\text {rd }}$ day. Monocytes, eosinophil and basophils percentages did not show any significant changes (Table-4).

Table -4- Total Leucocytes Counts and Differential Leucocytes Count of Rabbits in Experiment.

\begin{tabular}{|l|l|l|l|l|l|}
\hline \multirow{2}{*}{ Parameters } & \multirow{2}{*}{ Group } & \multicolumn{4}{|c|}{ Day } \\
\cline { 3 - 6 } & & \multicolumn{1}{|c|}{0} & \multicolumn{1}{|c|}{23} & \multicolumn{1}{c|}{54} & \multicolumn{1}{c|}{56} \\
\hline \multirow{2}{*}{ WBC X103/ cmm } & I & $5.106 \pm 0.48$ & $4.832 \pm 0.422$ & $4.118 \pm 0.368$ & $4.22 \pm 0.367$ \\
\cline { 2 - 6 } & II & $4.668 \pm 0.434$ & $5.044 \pm 0.689$ & $4.786 \pm 0.115$ & $5.833 \pm 0.555$ \\
\hline \multirow{2}{*}{ Heterophils\% } & I & $43.6 \pm 8.27 \mathrm{a}$ & $32.75 \pm 3.64 \mathrm{a}$ & $40.67 \pm 0.33 \mathrm{a}$ & $41.85 \pm 0.27 \mathrm{a}$ \\
\cline { 2 - 6 } & II & $41.4 \pm 4.46 \mathrm{a}$ & $40.2 \pm 5.54 \mathrm{a}$ & $40.4 \pm 4.15 \mathrm{a}$ & $41.57 \pm 5.56 \mathrm{a}$ \\
\hline \multirow{2}{*}{ Lymphocytes. \% } & I & $50.4 \pm 8.29 \mathrm{a}$ & $61.75 \pm 4.33 \mathrm{a}$ & $52.67 \pm 0.88 \mathrm{a}$ & $53.86 \pm 0.76 \mathrm{a}$ \\
\cline { 2 - 6 } & II & $46.2 \pm 4.05 \mathrm{a}$ & $52.2 \pm 5.85 \mathrm{a}$ & $48 \pm 3.46 \mathrm{a}$ & $47 \pm 5.94 \mathrm{a}$ \\
\hline Eosinophils. \% & I & $2.8 \pm 0.37 \mathrm{a}$ & $2.75 \pm 0.48 \mathrm{a}$ & $4.33 \pm 0.58 \mathrm{~b}$ & $2.25 \pm 0.25 \mathrm{a}$ \\
\cline { 2 - 6 } & II & $2.6 \pm 0.40 \mathrm{a}$ & $2.6 \pm 0.51 \mathrm{a}$ & $2.37 \pm 1.31 \mathrm{a}$ & $3 \pm 0.71 \mathrm{a}$ \\
\hline Basophils. \% & I & $1 \pm 0.32$ & $0.75 \pm 0.48$ & $0.66 \pm 0.11$ & $0.75 \pm 0.25$ \\
\cline { 2 - 6 } & II & $1.5 \pm 0$ & $1.8 \pm 0.37$ & $1.27 \pm 0.35$ & $0.72 \pm 0.27$ \\
\hline Monocytes. \% & I & $2.2 \pm 0.2$ & $2 \pm 0$ & $3 \pm 0.58$ & $2 \pm 0.21$ \\
\cline { 2 - 6 } & II & $2.5 \pm 0.55$ & $2.8 \pm 0.80$ & $2.4 \pm 0.42$ & $3.29 \pm 0.48$ \\
\hline
\end{tabular}

Values are $M \pm$ SEM: I treated group; II. Non treated group; $a, b$ significant difference at a level of $P<0.05$ in comparison with previous day

The results revealed that there was no pregnancy and infertility index was $0 \%$ in group I (non treated females crossed with treated males). While in group II (treated females crossed with non treated male) there was one rabbit pregnant from 5 (infertility index 20\%. Meanwhile in group III (both male and female non treated) they fertility index was 100\% (Table-5- ). 
Effect of Melia azedarach on The Reproductive Efficiency in Female Rabbits

Mayada Nazar Al-Khafaji

Table -5- Numbers of Pregnant, Non-pregnant Females, Total Numbers, and Infertility Index of Rabbits in Experiment.

\begin{tabular}{|c|c|c|c|c|}
\hline Groups & Pregnant & Non pregnant & Total & Infertility index \\
\hline I & 0 & 5 & 5 & $0 \%$ \\
\hline II & 1 & 4 & 5 & $20 \%$ \\
\hline III & 5 & 0 & 5 & $100 \%$ \\
\hline
\end{tabular}

I. Females non treated crossed with treated male

II. Female treated crossed with non treated male

III. Female non treated crossed with non treated male

The results revealed significant decrease in fetus numbers in female treated with Melia extract, and those crossed with treated male in comparison with those of non treated female and male. The results revealed decrease in body weight, length of the body, and width of skull of fetuses found in uterine at time of killing of females, and treated females, giving normal birth in comparison with those from non treated female. The results revealed that treatment with Melia extract for 53 days did not affect the length of pregnancy in female treated with Melia extract as the periods remain 30-32 days. (Table-6- ).

Table -6- Showing Weight, Length, and Width of Skull of Fetuses obtained from Female Rabbits in treated and Non treated Groups

\begin{tabular}{|c|c|c|}
\hline Parameters & Non treated & treated \\
\hline Body Weight of Fetuses $\backslash \mathrm{gm}$ & $43.33 \pm 2.4$ & $28 \pm 2.5$ \\
\hline Body Length of Fetuses $\backslash \mathrm{mm}$ & $90.67 \pm 3.44$ & $83.6 \pm 1.89$ \\
\hline Width of Fetuses Skull $\backslash \mathrm{mm}$ & $24.5 \pm 0.22$ & $14.67 \pm 9.42$ \\
\hline
\end{tabular}

The results revealed that levels of ALT, AST and AP were higher in treated females in comparison with those of non treated females but they are within normal ranges except AP was higher than normal level. Values of FSH, LH, Prolactin and testosterone less than normal levels, but there were no differences between those of treated and non treated females (Tbale-7- ). 
Effect of Melia azedarach on The Reproductive Efficiency in Female Rabbits

Mayada Nazar Al-Khafaji

Table -7- Levels of ALT, AST, AP, FSH, LH, Prolactin and Testosterone of Female Rabbits in treated and Non treated Groups.

\begin{tabular}{|c|c|c|c|}
\hline \multirow{2}{*}{ Groups $\backslash$ Parameter } & \multicolumn{2}{|c|}{ Female } & \multirow{2}{*}{$\begin{array}{c}\text { Normal } \\
\text { values }\end{array}$} \\
\cline { 2 - 3 } & Treated & Non treated & $10-35$ \\
\hline ALT u/l & 32.3 & 9.95 & $0-40$ \\
\hline AST u/l & 16.7 & 5.22 & $35-129$ \\
\hline AP u/l & 166 & 71.95 & $6.3-24$ \\
\hline FSH mlU/ml & $<0.1$ & $<0.1$ & $9.6-70$ \\
\hline LH mlU/ml & $<0.1$ & $<0.1$ & $0.7-19$ \\
\hline Prolactin ng/ml & 0.047 & 0.047 & 0.1 \\
\hline Testosterone ng/ml & $<0.025$ & $<0.025$ & \\
\hline
\end{tabular}

\section{$\underline{\text { Discussion }}$}

The reduced of pregnancy volume in female crossed with male treated with Melia azedarach can resulted from many variants in fertility, in the top of which the reduction in sperm counts, increased dead sperm numbers, and the percent of sperm deformity, in addition to disturbance of epididymis functions under the effects of androgens (10). The reduction in fertility also increased due to disturbances of functions of accessory sexual organs which supply seminal plasma which is important for continuity of sperms life $(10 ; 11)$. Increase in embryonic resorption and reduced weight of embryos can attributed to sperm deformity, as many of these deformity can lead to inhibition of embryonic development, or may be results from deformity of endometrium functions before arriving of embryos (12). and this proved by the histological changes in uterus which showed hyperplasia of uterine glands, and degeneration with thickening of myometrium. The intoxication of females can lead to embryonic resorption and reduced their weights and their death (13). Reduction in fertility was observed due to leucocytes infiltration in uterus resulting in inhibition of implantation and blockage of pregnancy $(14,15)$. Secondly, anti- implantation activity has been reported due to histopathological changes produced by inhibition of estrogen which induced changes in the uterus (16). Thirdly, the cause of implantation losses was observed due to steroidogenic depression evidenced by reduced plasma progesterone: estrogen ratio (17). Fertility index in adult cyclic rats after 18 days of treatment by dharek seed extract was reduced with the increase in dose as compared with the control group $(4,18)$. This supports the findings of (2) who observed reduction in fertility after 
Effect of Melia azedarach on The Reproductive Efficiency in Female Rabbits

Mayada Nazar Al-Khafaji

vaginal administration before mating and unilateral administration of neem oil in the uterus of female Wistar rats.

Serum levels of luteinizing hormone were lower significantly in group treated with methanol leaf extract of Azadirachta indicia orally at 200 and $400 \mathrm{mg} / \mathrm{kg}$, while there were significant higher progesterone levels, follicle stimulating hormone levels were however not different from the control. the histomorphic studies revealed no obvious pathological changes in the ovaries and uteri of the treated groups. (200 mg / kg, and $400 \mathrm{mg} / \mathrm{kg}$ of methanol extract of the leaf of A. index does not have any obvious effect on the histomorphologies of the ovary and uterus, but showed significant changes in the serum levels of LH and PH of female Wistar rat, implying that the effect of the extract may have been at a level other than these organs of the study (2). $(14,19)$ reported normal uterine and ovarian morphologies, and functions with the seed oil extract of A. indica. (20) reported normal histoarchitecture of the uterus of rats treated with neem oil extract (21) reported reduction in serum LH levels after treatment with extract of $A$. indica, while (20) reported that neem oil did not possess any estrogenic, anti-estrogenic or progestsational activity, while appearing not to have interfered with the actions of progesterone $(5,14,22)$ reported folliculogenesis inhibition, prolonged diestrus and partial blockage of ovulation, as well as, enhanced antigen - presenting ability of the uterus with seed and oil extracts of $A$. indica.

Significant damage to the luminal epithelium of the uterus and to the uterine glands, with decreased glycogen and total protein contents in the ovary and uterus, has also been reported on administration of oil of neem to cyclic and ovariectomized rats (23), while (24) reported alterations in morphologies and functions of the uterus in rats treated with the seed extract of neem.Number of retrieved unimplanted embryos has been found to have the attached leucocytes to the zona pellusida layer it is believed that this secretion of leucocytes might be responsible for under development of early embryo or by initiating a cellular immune response in the uterus leading to blocking of implantation $(14,15)$.

The anti-estrogenic quality of neem oil also explains its anti-implantation effect. But the post implantation effect, which caused implanted fetuses to be either resorbed or expelled, also may be due to direct toxicity, fall in progesterone level or interference with the uterine utilization of progesterone (25). 
Effect of Melia azedarach on The Reproductive Efficiency in Female Rabbits

Mayada Nazar Al-Khafaji

The treated males with Melia azedarach in this study lead to increase the percent of dead sperms in epididymis tail, and this may be due to presence of spermicidal material. (26).

\section{Conclusion}

Melia azedarach lead to increase the percent of dead sperm in epididymis tail, so work as antifertility and anti-implantation

\section{$\underline{\text { References }}$}

1. Mohammad A. (2013). A Review on Spermicidal activities of Azadireachta indica. Journal of Pharmacognosy and Phytochemistry; 1 (5): 62- 80.

2. 2.Vishnukanta, A. C. R. (2009). Antifertility activity of Melia azedarach Linn (Meliaceae) in female Wistar rats. Pharmacology on line; 2: 117-132.

3. Harlow, W.M., Harrar E.S., Hardin J.W. and White, F.M. (1996). Text book of Dendrology. 8th ed. McGraw-Hill, Inc.: 461.

4. Reshu M,. and Patwant Kaur Dhaliwal (2007). Antifertility effect of Melia azedarach Linn. (Dharek) seed extract in female albino rats. Indian Journal of Experimental Biology.; 45 (October): 853-860.

5. Roop, J.K.; Dhaliwal, P.K. and Guraya, S.S. (2005). Extracts of Azadirachta indica and Melia azedarach seeds inhibit folliculogenesis in albino rats. Brazilian Journal of Medical and Biological Research; 38 :953- 947.

6. Keshri, G.; Lakshmi, V., and Singh, MM. (2003). Pregnancy interceptive activity of Melia azedarach Linn. In adult female Sprague- Dawley rats. Contraception; 68:303306.

7. Choudhary, R.R. (1966). Plants with possible antifertility activity. Special Report (Indian council Med. Res., New Delhi).

8. Coles, E.H. (1986). Veterinary Clinical Pathology, 4th ed. W.B. Saunders Company, Philadelphia, USA: 10-75.

9. Steel, R.G., and Torrie, J.H. (1985). Principles and Procedures of Statistics, a Biometrical Approach ", 2nd ed., McGraw- Hill, Inc., Singapore: 183. 
Effect of Melia azedarach on The Reproductive Efficiency in Female Rabbits

Mayada Nazar Al-Khafaji

10. Hafez, E.S.E. (1978). Human Reproductive Physiology. Ann. Arbor Science Publishers Inc. London: 407- 699.

11. Waller, D.P., Killinger, J. M., and Zaneld, L.J.D. (1985). Physiology and toxicology of the male reproduction tract In: Endocrine toxicology edited Thomas J.A.Raven Press, New York: 213-219.

12. Chaves, D.J., and Anderson, T.L. (1985). The glycocalyx of the mouse uterine luminal epithelium during estrus , early pregnancy, the pre- implantation period , and delayed implantation. Acquisition of Ricinus communis, binding sites during pregnancy. Biology of Reproduction; 32: 1135-1142.

13. Al-Kofahi, A., Al-Hamood, M.H., and Elbetieha, A. (1996). Antifertility evaluation some medicinal plants in male and female mice. Archives of STD/ HIV; 10- : 189 196.

14. Upadhyay, S.N.; Kaushic, C. and Talwar, G.P. (1990). Antifertility effects of neem (Azadirachta indica) oil by single intrauterine administration: A novel method for contraception. Proc. R. Soc. Lond. B Biol. Sci.; 242: 175-179.

15. Juneja, S.C.; Williams, R.S.; Farooq, A. and Chegini, N. (1996). Contraception potential of neem oil: Effect on pregnancy success in the mouse. J. Assist. Repro Genet; 13 (7): 578 .

16. Pakrashi, A. and Chakrabarty, B. (1978). Antioestrogenic and anti - implantation effect of sristolic acid from Aristolochia indica (Linn). Indian J. Exp. Biol.; 16: 1283.

17. Adhikary, P.; Chowdhury, D.; Banerji, J.and Chatterjee, A. (1998). Antifertility effect of crude alcoholic extract of Piper betlestalk. Indian J. Physiol. Allied Sci.; 52:22.

18. Sinha, K.C.; Riar, S.S.; Bardhan, J.; Thomas, P.; Kain, A.K.and Jain, R.K. (1984a). Neem oil as a vaginal contraceptive. Indian J. Med. Res.; 79: 131.

19. Amabe, O. A.; Moses, B. E.; Kelechi, C. U.; Mfon, A.; Mokutima, A./E.; Theresa, B.E. (2010). Gonadal histomorphologies and serum hormonal milieu in female rats treated with Azadirachta indica leaf extract. Iranian Journal of Reproductive Medicine; 8 (4): 185- 190 .

20. Prakasha, AO. Tewaria, RK., and Mathur, R. (1988). Non - hormonal post - coital contraceptive action of neem oil in rats. J. Ethanopharmacol; 23: 53-59. 
Effect of Melia azedarach on The Reproductive Efficiency in Female Rabbits

Mayada Nazar Al-Khafaji

21. Ragi, Y.; Udoh, US.; Mewoyeka, OO.; Ononye, FC. and Bolasrinwa, AF. (2003). Implication of reproductive endocrine malfunction in male antifertility efficacy of Azadirachta indica extract in rats. Afr. J. Med. Sci. 32: 159- 165.

22. Gbotolorun, SC.; Oremosu, AA; Noronha, CC., and Okanlawon, OA. (2004). the effect of alcohol extract of neem seed on ovulation, estrous cycle, and the fertility of adult cyclic Sprague - Dawley rats. Nig. J. Health Biomed Sci.; 3: 116- 119.

23. Tewaria, RK.Pathaka, S.,and Prakash, AO. (1989). Biochemical and histological studies of reproductive organs in cyclic and ovarioectomized rats supporting s a non hormonal action for neem oil. J. Ethanopharmacol; 25: 281-293.

24. Mandal, R. and Dhaliwal, PK. (2007). Antifertility effect of Melia azedarach Linn (dharek) seed extract in female albino rats. Indian Exp. Biol; 45: 853- 860.

25. Riar, S.S.; BardhaN, J.; Thomas, P.; Kain, A.K. and Parshad. (1988). Mechanism of antifertility action of neem oil. Indian J. Med. Res.; 88: 339.

26. Sinha, K.C.: Riar, S.S.; Tuwari, R.S.; Dhawan, A.K.; Bardhan, J. Thomas, P.Kain, A.K.; and Jaion, R.K. (1984b). Anti- implantation effect of neem. Indian J. Med. Res.; 80: 708. 